\title{
Video games in teaching-learning processes: A brief review
}

\section{Edgar Manuel Cano Cruz, Juan Andrés Velázquez Cruz, Juan Gabriel Ruiz Ruiz, Luis David Huerta Hernández}

Computer Science Department, University of the Istmo Region, Ixtepec, Mexico

\section{Email address:}

edgarcano@bianni.unistmo.edu.mx (E.Cano)

\section{To cite this article:}

Edgar Manuel Cano Cruz, Juan Andrés Velázquez Cruz, Juan Gabriel Ruiz Ruiz, Luis David Huerta Hernández. Video Games in Teaching-Learning Processes: A Brief Review. International Journal of Secondary Education. Vol. 2, No. 6, 2014, pp. 102-105. doi: $10.11648 /$ j.ijsedu.20140206.12

\begin{abstract}
Along with knowledge acquisition, techniques and procedures, the goal of education is to develop individuals capable of reacting to planned or unplanned circumstances, making decisions in a set time. The focus of digital game-based learning (DGBL) under an instructional framework context, pedagogical standards link where computer games are an integral part of learning. You teach with computer games for teaching content, has the potential to positively influence the motivation of students to learn and retain knowledge. In this article we have reviewed literature in this field and determined whether the use of computer games, especially in mathematics, contributes to a more efficient implementation of educational objectives at all levels of education.
\end{abstract}

Keywords: Digital Games-Based Learning, Educational Technology, Innovative Education Strategies, Educational Software, Serious Games, Gamification

\section{Introduction}

In the generation called "digital natives", capturing the attention of students in traditionally difficult areas such as Mathematics is becoming more difficult [1]. In this context, traditional methods of teaching and learning are gradually become obsolete. The DGBL has emerged as an alternative strategy to support the teaching and learning processes [2].

In a few years it has become popular to incorporate video games and the use of digital technology in education which guide the traditional learning methods, obtaining more constructive classes, where the focus is the student and the teacher acts as a guide [3]. Video games provide a framework from making the choice between conventional bonds where students are encouraged to synthesize information and analyze strategies for a greater understanding to the solution of a proposed problem.

The use of games in everyday life among children and young, is the subject of constant concern to teachers and parents, and that video games can generate addiction, spending too much time exposed to the screens, or cause a lack of practice in other areas holistic and social development such as reading and sports. It is important to teaching on the use of media and exploit them for education.

This article's main objective is to provide elements of analysis to help understand the relationship between uses of video games in learning. In the next section the evolution of video games in an educational context and a brief classification of these presents; then, in the third section a literature review focused on the use of the approach DGBL highlighting features for inclusion in education systems is performed; later in the fourth section are mentioned for the realization or choice of an educational video game; Finally, the fifth section concludes this article.

\section{Video games in Education, Evolution and Classification}

Within the educational framework, there are various definitions to describe the term "educational game" or also known in the area as serious games, one of the best definitions attached in an instructional context provided by Salen and Zimmerman in the book Rules of Play: Game Design Fundamentals [5]: "A game is a system where players are driven to an artificial conflict, defined by rules, where the result is a quantifiable measure".

Another definition of the video game within the educational context is given by Raph Koster in his book A Theory of Fun [6], using the term "serious game" to describe this digital 
game and contain artificial problems governed by rules, experiment with the emotional reactions of the players. Koster defines a video games as a system to motivate players in an abstract challenge, defined by rules, interactivity and feedback, where the result is a quantifiable output. In this sense, the video games are a set of specific multimedia systems with the main objective to entertainment.

As for the evolution of educational games in the doctoral thesis and subsequent publications of Egenfeldt-Nielsen [7, 8], educational gaming generations are identified based on learning theories employed. The first generation corresponds to the perspective of the concept called edutainment, wherein it is assumed that learning occurs when practiced several times specific techniques. The majority of this type of educational video games failed because they were too simplistic compared to gaming entertainment in general. The activities of this first generation were too repetitive, poorly designed and did not encourage a progressive learning.

Later in the second generation, studies on cognition and the first applications of constructivism demonstrated the need to focus the design on the learner, which gave rise to the "facilitators" directly (aid, tutorials, etc.) and indirect (sounds, visual clues, etc.).

In the third generation not only the content of a specific game is emphasized, but also stressed in the learning process according to the context and particular attention is placed on situated learning. Teachers act as facilitators adapting video games to their chairs.

The design evolution has led to the sophistication of visual aspects and effects of three-dimensional, virtual reality, etc. However, a good graphic development does not imply that it is sufficient to keep the attention and interest of the player parameter. The story remains an important factor for the success of a game [9].

As for the classification of video games, the industry, developers and academics use different taxonomy to differentiate the types of games. Table 1 lists the most important genres in base [7].

Table 1. Category video games [7].

\begin{tabular}{|c|c|}
\hline Category & Description \\
\hline $\begin{array}{l}\text { Action/platfor } \\
\mathrm{m} \text { games }\end{array}$ & $\begin{array}{l}\text { These games are reaction based; most of the games of } \\
\text { the first generation are action games. }\end{array}$ \\
\hline $\begin{array}{l}\text { Adventure } \\
\text { Games }\end{array}$ & $\begin{array}{l}\text { The player solves a number of tests in order to progress } \\
\text { through a virtual world. }\end{array}$ \\
\hline $\begin{array}{l}\text { Fighting } \\
\text { games }\end{array}$ & $\begin{array}{l}\text { These games involve fighting against } \\
\text { computer-controlled characters or those controlled by } \\
\text { other players. }\end{array}$ \\
\hline $\begin{array}{l}\text { Role-playing } \\
\text { games }\end{array}$ & $\begin{array}{l}\text { Human players assume the characteristics of some } \\
\text { person or creature. }\end{array}$ \\
\hline Simulation & $\begin{array}{l}\text { The player has to succeed within some simplified } \\
\text { recreation of a place or situation to achieve a particular } \\
\text { goal. }\end{array}$ \\
\hline Sport games & These games are based on sports \\
\hline $\begin{array}{l}\text { Strategy } \\
\text { games }\end{array}$ & $\begin{array}{l}\text { These games that recreate a historical or fictional } \\
\text { situation to allow a player to devise an appropriate } \\
\text { strategy to achieve a goal. }\end{array}$ \\
\hline
\end{tabular}

\section{Analysis Inclusion of the Video Games in Education}

Cameron \& Dwyer [10], considered the relationship between playing video games and complete educational goals and determined how video games computer influence the realization of educational objectives, based on information made to 422 students which shows that occupy this type of software provides an important strategy to motivate students in obtaining significant knowledge at all educational levels. Young \& Loverdige [11], they investigated about learning math concepts about children, their exploration is based on establishing how video games affect their knowledge assimilation techniques in the investigation about 106 students participated; the results obtained showed very marked improvements over children occupied for learning games against those who did not use these tools, the results were consistent for a year, demonstrating that learning math for kids five years was faster and easier using video games. For children the first event of learning mathematical concepts was a game, resulting in a fun activity and strengthen positive.

Another study conducted in Chile by Rosas et al. [12], indicates a significant difference from 1274 students divided into three groups: experimental, control and external; the investigation was designed specifically for children in first and second grade. The experimental group was subjected to thirty hours of interaction with video games within three months. The result in favor of the experimental group revealed that: "video games were a key factor in increasing motivation and learning of mathematics for this group in particular".

The study conducted by Nussbaum and his colleagues [13], was the development of a series of games using the Gameboy handheld console learning of language and mathematics. Nussbaum evidenced for that video games are actually implemented in the classroom, it is essential that teachers encourage their use becoming active mediators making the most of their educational potential by relating directly to the objectives and content taught in other school activities. In this way the teacher must possess not only a good command of the machine, but also of educational objectives that each game promotes. Thus, it can properly be included in the planning of the school year and effectively used as a supplement to other instructional materials.

Accordingly, adequate teacher training and direct support in the initial stage of technology transfer is essential to align the use of the tool to each particular educational context and reduce fear and distrust that causes these tools.

McFarlane, Sparrowhanwk and Heald [14], they studied in the United Kingdom the impact of learning using video games. The study was applied to teachers in different grades of primary and secondary education, reporting about the limits and potential that video games had in the teaching-learning; reflecting that most teachers had positive views about video games (adventure and simulators) used for the subject of Mathematics, contributing to the development of a variety of strategies that are extremely important for learning, such as resolution problems, sequential learning, deductive reasoning, 
memory, among others. Also, McFarlane found an increase in the effectiveness of strategies for teamwork and it is possible to add specific instructional activities and mix the DGBL approach with other learning approaches such as the Problem Based Learning. The reporting of MacFarlane also presents a comprehensive overview on the implementation of DGBL in various areas.

Table 2. Areas of learning in which videogames can contribute [14].

\begin{tabular}{ll}
\hline Areas & Aspects videogames can contribute \\
\hline $\begin{array}{l}\text { Personal and social } \\
\text { development }\end{array}$ & $\begin{array}{l}\text { Provide interest and motivation to learn; Maintain } \\
\text { attention and concentration.. } \\
\text { Language and } \\
\text { literacy }\end{array}$ \\
$\begin{array}{l}\text { Encourage children to explain what is happening; } \\
\text { Use talk to organize, sequence and clarify thinking, } \\
\text { ideas, feelings and events } \\
\text { development }\end{array}$ & Use everyday words to describe position \\
$\begin{array}{l}\text { Creative } \\
\text { development } \\
\text { Knowledge and } \\
\text { understanding of the } \\
\text { world }\end{array}$ & $\begin{array}{l}\text { Respond in a variety of ways; Use their } \\
\text { imagination in art and design music, and stories. } \\
\text { ahysical } \\
\text { and control. }\end{array}$ \\
\hline
\end{tabular}

The opinions of teachers in the study of McFarlane in the United Kingdom reflect the views of the Chilean teachers interviewed by Nussbaum. Table 2 lists the common features found in these two studies.

The work conducted by Divjak [15], sample a review and classification of different items which were applied math video games, the aim of this review is to summarize the results of the inclusion of video games based on the following questions:

- P1: What is the impact of video games on the realization of educational objectives at all educational levels?

- P2: How has influenced the use of video games in motivation and attitude of students about mathematics?

- P3: How have influenced the game in achieving educational goals regarding groups that were not used?

Table 3 presents a summary of five articles (2008-2010) of the investigation of Divjak, highlighting the degree, number of participants, country focus and answers to questions previously raised in the following format applies: $(+)$ positive negative $(-)$, undetermined impact $(\sim)$ and question not considered (no).

Table 3. Review and analysis of videogames in education [15].

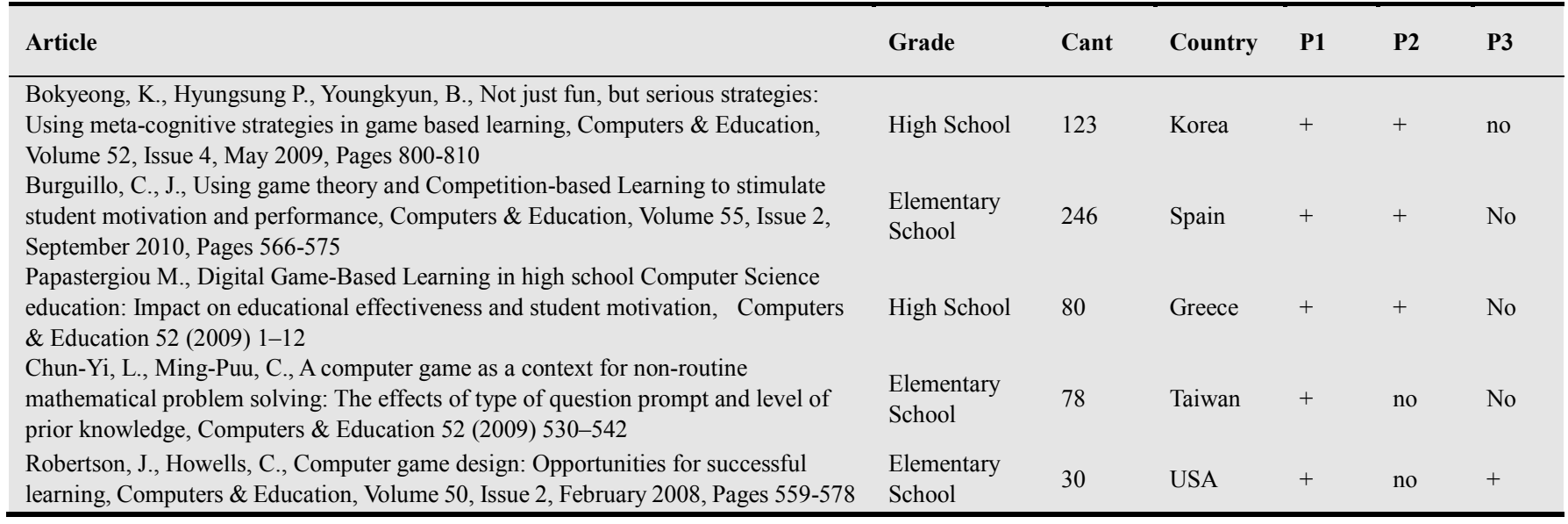

\section{Aspects of a Videogame for Teaching and Learning}

As reviewed in the previous section, with the use of video games students can acquire manual skills, coordination, spatial orientation; in some situations the use of cognitive strategies such as decision making and problem solving necessary; allow you to strengthen values and norms of behavior and the ability to generate situations of interaction with other playmates and cooperative learning. Gifford [16], raises a number features to consider in conducting or choose video games as a learning, among the most important characteristics are:

1. Should permit the exercise of fantasy, no spatial, temporal or gravity limitations.

2. Must facilitate access to "other worlds" and sharing each other through graphics, contrasting sharply with conventional classrooms and static.

3. Should encourage replay and try and try again in a safe environment.

4. They should allow mastery of skills. Although difficult, players can repeat the actions, up to dominate, gaining a sense of control.

5. They must have clear objectives. Usually, the player does not know what is being studied in the game, but when playing knows there is a clear and concrete (open a door, rescue someone, find treasure, etc.) task, which provides high level of motivation.

Klawe conducted an investigation in [16], to determine the factors that need video games to impact directly on student learning and meet the expectations of teachers. Klawe asserts that if a game aims to increase motivation and make learning math easier, you should consider the following:

- Specific topics of the subject to learn.

- Learning activities based on an instructional model. 
- A model (or models) basic learning.

- An interface to manipulate words and objects.

- A form and conception of how to present content.

- A navigation structure and order of instructional activities.

- Feedback of activities and,

- Elements of fun (graphics, sound, story, characters, humor, etc.).

The requirements to adequately cover curriculum plans, are mentioned by Gros [9], highlighting the importance of designing a guide to explain the goals of the game and the merits to be performed to complete the levels of each game.

Another aspect and in accordance with Prensky [17], for a digital game serves as a tool for teaching and learning, it must be designed and developed under the scheme of a complex game, work with tools to measure and assess the progress of learning. In this regard, trivia games are easily completed in an hour or less, unlike more sophisticated complex games requiring at least 10 hours to identify and negotiate complex relationships between real and simulated characteristics.

\section{Conclusions}

According to the literature review in this research, one of the main disadvantages of video games and DGBL approach in classrooms, is the amount of time it takes to both students and teachers adapt video games the curricular plans; as this process demanded them considerable effort and impacting the rejection of some teachers to focus DGBL. Another notable discussion lies in the design of online gaming environments (history, settings, etc.), since often are usually referrals and defendants to violent themes and even misogynistic simplified representation of reality. For this reason, many critics of the approach DGBL suggest that digital games based learning is not the right way to teach academic purposes; however, recent results have shown a remarkable growth in the cooperative, instructional and new mechanism in the development of problem solving strategies development. Also, as part of the analysis, it is observed that most of contributions concerning the inclusion of video games in education systems are qualitative character, so much remains to study and obtain quantitative results really show the direct and the impact of video games on the processes of teaching-learning.

Video games are not the solution to educational problems, however, the main idea is to change the traditional teaching methods to motivate the younger generation (digital natives) and change the paradigm of knowledge assimilation.

As indicated by the prospect of the third generation of educational games, is vital management learning theories in conjunction with the appropriate design of instructional activities to cover comprehensively the teaching-learning process. Educational video games are not a substitute teacher in the classroom, but a complement to it that will serve as a tool to potentiate the cognitive ability of their students and always guided by an instructional framework in context.

\section{References}

[1] Prensky, M. "Digital, Natives, Digital.Immigrants". MCB University Press, Vol. 9 No. 5, October 2001.

[2] (2012) What does it mean to be a digital native? [Online]. Available in: http://edition.cnn.com/2012/12/04/ business/digital-native-prensky/

[3] Prensky, M. (2003). Digital game-based learning. ACM Computers in Entertainment, 1(1), 1-4.

[4] Amory, A. "Learning to play games or playing games to learn? A health education case study with Soweto teenagers". Australasian Journal of Educational Technology. Vol. 26 No .6, pp: 810-829, 2010.

[5] Salen, K., \& Zimmerman, E. (2004). Rules of play: Game design fundamentals. Cambridge, MA: MIT Press, p. 80.

[6] Koster, R. (2005). A theory of fun for game design. Scottsdale, AZ: Paraglyph Press, p. 34.

[7] Egenfeldt-Nielsen, S. Beyond edutaiment. Unpublished dissertation, University of Copenhagen. Denmark. (2005).

[8] Egenfeldt-Nielsen, S. Third Generation Educational Use of Computer Games Jl. of Educational Multimedia and Hypermedia, Vol. 16, No. 3. 2007

[9] Begoña, G., Bernat, A., Catalá, A., Fexia, C., Grupo F9. Videojuegos y Aprendizaje. Editorial GRAÓ. 2008.

[10] Cameron, B., Dwyer, F., The effects of online gaming, cognition and feedback type in facilitating delayed achievement of different learning objectives. Journal of Interactive Learning Research, 16(3), (2005) 243-258.

[11] Young-Loveridge J. M., Effects on early numeracy of a program using number books and games, Early Childhood Research Quarterly, 19 (2004) 82-98.

[12] Rosas, R., Nussbaum, M., Cumsille, P., Marianov, V., Correa, M., Flores, P. Beyond nintendo: design and assessment of educational video games for first and second grade students. Computers \& Education, 40(1), (2003) 71-94.

[13] Nussbaum, M., Rosas, R., Rodríguez, P., Sun, Y., Valdivia, V. Diseño, desarrollo y evaluación de videojuegos portátiles educativos y autorregulados. Ciencia al Día, 3(2), (2009) 1-20.

[14] McFarlane, A., Sparrowhawk, A., \& Heald, Y. (2002). Report on the educational use of games. [Online] http://www.teem.org.uk/

[15] Divjak, B., Tomic, D. The Impact of Game-Based Learning on the Achievement of Learning Goals and Motivation for Learning Mathematics-Literature Review. JIOS, 35(1), (2011).

[16] Klawe, M. M., When does the use of computer games and other interactive multimedia software help students learn Mathematics? (1998) Unpublished manuscript. http://www.cs.ubc.ca/nest/egems/reports/NCTM.doc

[17] Prensky, M. Complexity Matters Mini-games are Trivial - but "Complex" Games Are Not. Educational Technology Vol. 45 No.4 July-Aug 2005.

[18] Kapp, K. The Gamification of Learning and Instruction. Jhon Wiley \& Sons. 2012. 